\title{
Preparation of High Purity Si Powder by SHS
}

\author{
Chang Yun Shin, Hyun Hong Min, Ki Seok Yun, and Chang Whan Won ${ }^{\dagger}$ \\ Engineering Research Center for Rapidly Solidified Materials, Chungnam National University, Daejeon 305-764, Korea \\ (Received November 13, 2006; Accepted January 8, 2007)
}

\section{자전 연소 합성법에 의한 고순도 실리콘 분말제조 \\ 신창윤 · 민현홍· 윤기석 · 원창환 ${ }^{\dagger}$ \\ 충남대학교 급속응고신소재연구소 \\ (2006년 11월 13일 접수; 2007년 1월 8일 승인)}

\begin{abstract}
High purity $\mathrm{Si}$ powder was prepared in the system of $\mathrm{SiO}_{2}-\mathrm{Mg}$ combustion reaction. Various conditions of combustion reaction and leaching were investigated. As the particle size of $\mathrm{Mg}$ decreased and the compaction pressure increased the quantity of the unreacted powder was decreased. In the acid leaching of $\mathrm{MgO}$, increasing particle size, reaction temperature, rotating speed and reaction time made leaching effect low. Final Si powder produced by combustion and leaching reaction, has a high purity of $99.9 \%$ with irregular shape.
\end{abstract}

Key words : Combustion, Leaching, Silicon, $\mathrm{SiO}_{2}, \mathrm{SHS}$

\section{1.서 론}

본 논문에서 제조하고자 하는 실리콘 분말은 사용범위 가 상당히 넓고 다양하다. 특히 실리콘 분말이 알루미늄 에 첨가되면 알루미늄의 유동성을 증가시켜 주조성을 좋 게 하므로 주조용으로 사용되는 $4 \mathrm{XXX}$ 계열의 알루미늄 합금제조에 필수불가결한 재료이며, 제철소의 환원제로도 크게 사용하고 있다. 또한 이러한 기초재료 외에 용접봉 및 VTR head drum 등 각종 기기부품의 제조에도 실리콘 은 다량 사용되고 있다. 근래에 들어 반도체재료로 그 사 용이 급증하고 있으며 특히 전자기기의 소형화가 요구됨 에 따라서 고순도 실리콘기판위에 집적회로를 만들어야 하므로 보다 큰 지름의 실리콘 단결정이 요구되어 진다. 따라서 고순도 단결정 실리콘재료를 만들기 위해서는 그 원료로서 고순도의 실리콘분말이 만들어져야만 한다..$^{1-3)}$ 이때 고순도 실리콘을 제조하는 방법으로는 주로 사염화 실리콘의 수소환원법이나 3 엄화실란의 수소환원법을 이 용하여 단결정용 실리콘분말을 만들게 되나 이때 염소 가 스의 발생으로 심각한 공해문제를 야기시키므로 주로 후 진국에서 생산하게 된다.

현재 우리나라는 주요 반도체 생산국이지만 그 원료는 대부분 수입에 의존하고 있으며 이에 대한 연구도 부족 한 실정이다. 따라서 국내 기간산업의 활성화 및 첨단화

\footnotetext{
${ }^{\dagger}$ Corresponding author: Chang Whan Won E-mail : cwwon@cnu.ac.kr

Tel : +82-42-821-7081 Fax : +82-42-822-9401
}

를 위해서 실리콘의 자체개발은 시급한 과제라 아니 할 수 없다. 이와 같은 즈음에 공해문제를 줄일 수 있는 자 전 연소 고온 반응법(SHS)은 공정이 단순하기 때문에 경 제적이며, 반응이 고온에서 진행되고 급냉되기 때문에 자 기 정제효과가 있어 금속분말 및 세라믹을 제련하는데 큰 효과가 기대 되는 공정이다. ${ }^{47}$ 따라서 이 SHS법을 이용 하여 실리콘을 제조 할 경우 그 순도가 약 $99.9 \%$ 이상으 로서 위에서 언급한 주조용 앝루미늄의 합금화 원소로 사 용이 가능하며, 그리고 몇 차례의 정련 단계를 거친다면 현재 반도체 재료의 원료로써 사용이 되고 있는 고순도 (순도 $99.99999 \%$ 이상) 실리콘의 제조가 가능하다.

\section{2. 실험 방법}

본 실험에서 사용된 자전연소반응기의 개략도와 사용 된 원료 분말의 특성을 Fig. 1 과 Table 1에 각각 나타내었 다. 원료분말들을 소정의 몰비로 칭량한 다음 polyethylene bottle에 알루미나 볼을 함께 장입한 후 볼밀에서 $350 \mathrm{rpm}$ 의 속도로 약 2시간 동안 건식 흔합하였다.

연소반응기의 재료는 SUS316강을 사용하였고, 반응기 내부는 진공 및 불활성 분위기 등을 조절할 수 있도록 제 작되었다. 반응기 내부는 진공과 분위기를 만들 수 있도 록 진공펌프와 in-gas valve가 장착되었고, 반응기 외부에 는 반응의 진행을 관찰할 수 있도록 내열·내압유리가 부 착되었다. Fig. 2에 본 실험의 공정도를 나타내었다. 시편 을 점화시키기 위하여 $\mathrm{Ni}-\mathrm{Cr}$ 필라멘트를 내부에 설치하 였다. 또한 반응기내에 C-type(W-5\%Re vs W-26\%Re) 열 


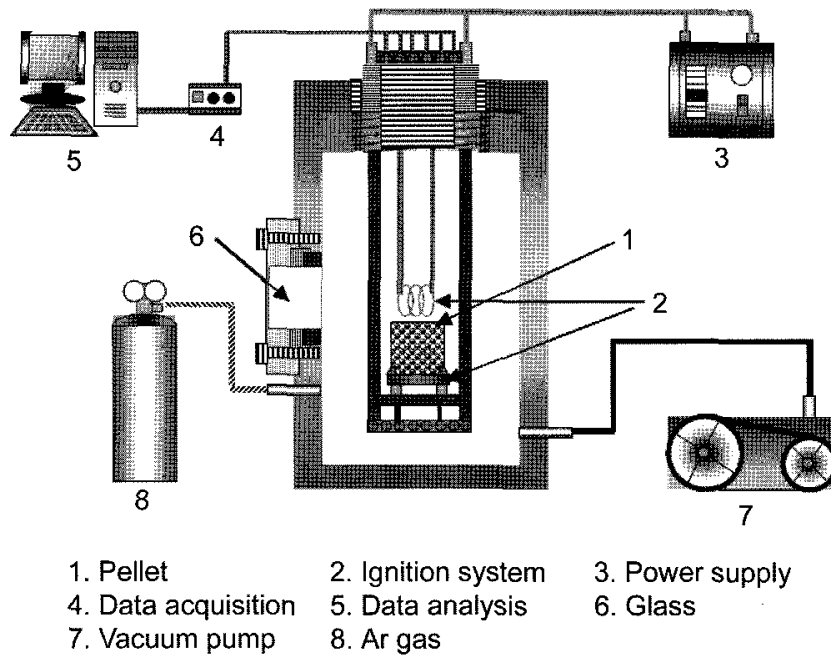

Fig. 1. Schematic diagram of SHS reactor.

Table 1. The Properties of Raw Materials Used in This Study

\begin{tabular}{cccc}
\hline Materials & $\begin{array}{c}\text { Particle size } \\
(\text { mesh) }\end{array}$ & $\begin{array}{c}\text { Purity } \\
(\%)\end{array}$ & Manufacturer \\
\hline $\mathrm{SiO}_{2}$ & $<325$ & 99.16 & $\begin{array}{c}\text { Samchun Chemical } \\
\text { (Daejeon, Korea) }\end{array}$ \\
$\mathrm{Mg}$ & $20 \sim-325$ & 99.8 & $\begin{array}{c}\text { Daejung Chemical } \\
\text { (Siheung, Korea) } \\
\text { Ar gas }\end{array}$ \\
\hline
\end{tabular}

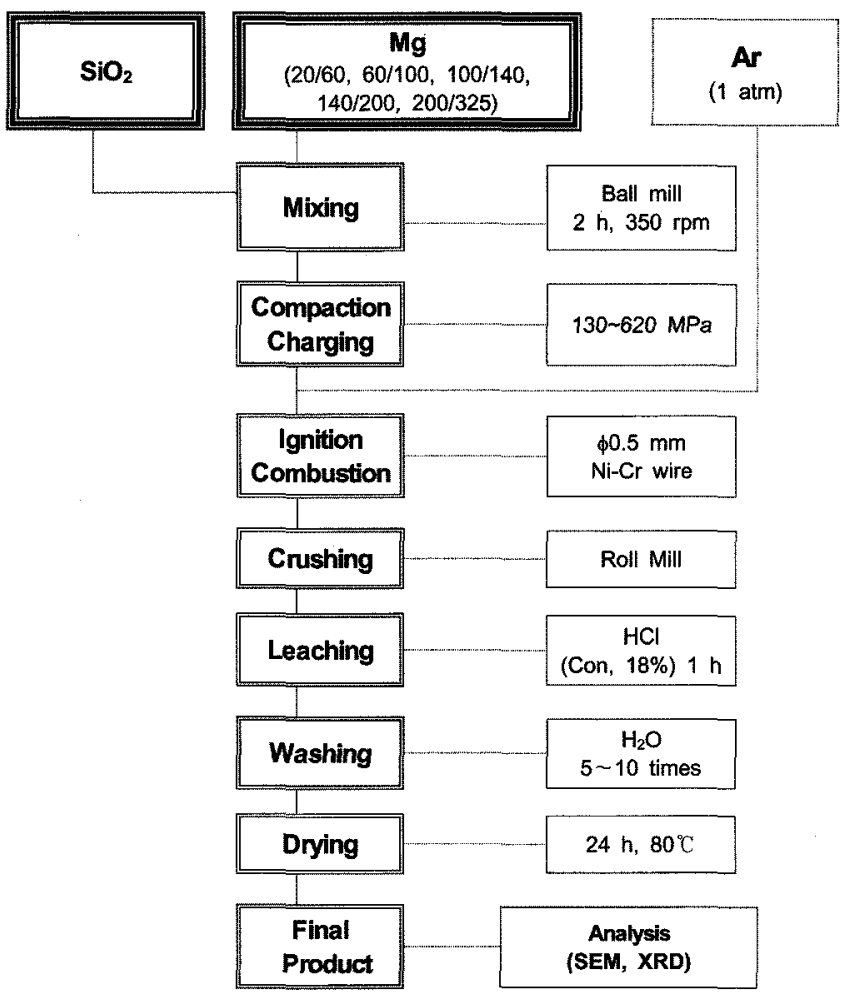

Fig. 2. Flow chart of experimental procedure.
전대를 설치하여 DASTC data logger를 통해 연소온도 및 냉각온도변화를 $10 \mathrm{~Hz}$ 의 표본추출비율로 측정할 수 있도 록 하였다. 혼합된 분말은 상온균일압축기(CIP, cold isostatic pressing)를 이용하여 지름 $30 \mathrm{~mm}$, 높이 $50-60 \mathrm{~mm}$ 의 원기 둥형 펠렛으로 제조하였고, 성형 압력의 변화에 대한 고 찰하기 위해 성형압력을 130 620 MPa로 변화시켜 예비 성형체를 만들었다. 이 예비성형체를 자전연소 고온반응 기내에 장착하여 내부를 진공상태로 유지한 다음, 아르곤 가스를 주입하여 압력을 $1 \mathrm{~atm}$ 으로 한 후 $\mathrm{Ni}-\mathrm{Cr}$ 필라멘트 (직경 $1 \mathrm{~mm}, 220 \mathrm{~V}, 60 \mathrm{~A}$ )로 점화시켰다.

반응 후 생성물은 -100 mesh로 분쇄하여 $\mathrm{MgO}$ 의 제거 를 위해 $\mathrm{HCl}(\mathrm{con} ., 18 \%)$ 용액으로 1 시간 동안 교반 침출 하여 고-액 분리하고 5 10회 수세한 후 건조하였다. 본 실험에서 얻은 생성물의 결정구조 분석은 XRD(SIEMENS 사, Model:D5000)를 이용하였다. 또한 생성물의 미세구 조를 관찰하기 위하여 SEM(JEOL사, Model:JSM-5410)을 사용하였고, 최종생성물의 성분분석은 ICP로 행하였다.

\section{3. 결과 및 고찰}

\section{1. 생성물에 미치는 $\mathrm{Mg}$ 첨가량의 영향}

본 실험에서 고순도 규소분말을 제조할 때의 반응식은 다음과 같다.

$$
\mathrm{SiO}_{2}+2 \mathrm{Mg}=\mathrm{Si}+2 \mathrm{MgO} \Delta \mathrm{G}_{298 \mathrm{~K}}=-281.442 \mathrm{KJ} / \mathrm{mol} \rightarrow
$$

위의 반응식 즉 화학양론비에 대한 표준자유에너지 값 은 음의 값을 가지므로 안정한 반응이 진행되고, $\mathrm{Mg}$ 은 산화시 다량의 열을 발생하므로 금속산화물을 환원시킬 때 환원제로 사용되는 것으로 알려져 있다.

상기 식에 의해 계산된 이론적인 단열반응온도는 $2200 \mathrm{~K}$ 의 높은 발열반응을 나타내기 때문에 반응이 안정하게 진 행 될 것으로 생각된다. Fig. 3 은 본 연구의 기본 반응계

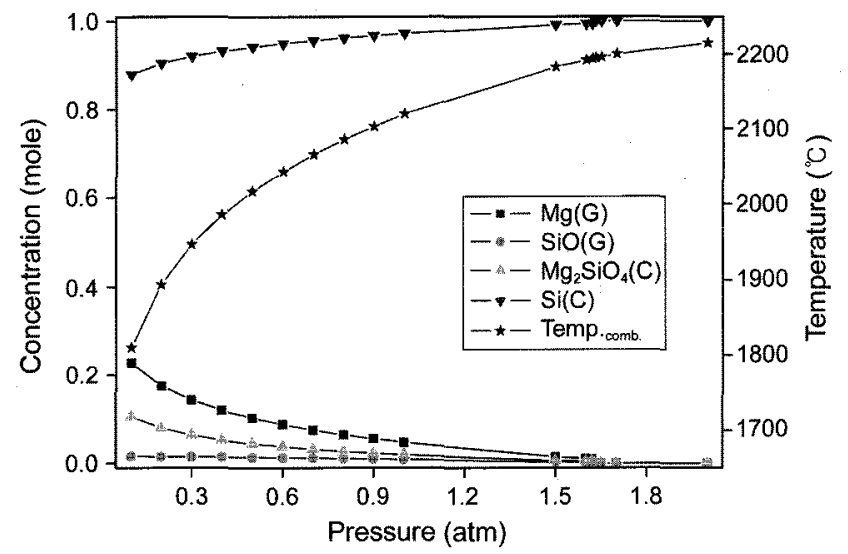

Fig. 3. Concentrations of reaction species with various initial pressure of inert gas in the reactor calculated by 'THERMO' program. 


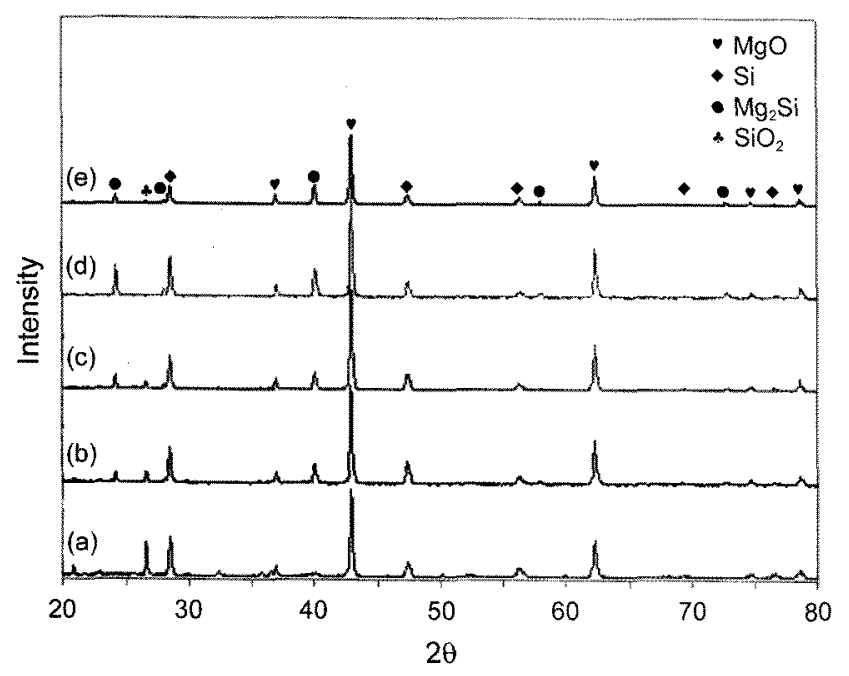

Fig. 4. X-ray patterns of reaction products varying with $\mathrm{Mg}$ molar ratio before leaching $(\mathrm{Mg}$ particle size $20 /$ $60 \mathrm{mesh}$, compaction pressure $130 \mathrm{MPa}$; (a) $2.0 \mathrm{~mol}$, (b) $2.2 \mathrm{~mol}$, (c) $2.4 \mathrm{~mol}$, (d) $2.6 \mathrm{~mol}$, and (e) $2.7 \mathrm{~mol}$.

인 상기반웅에 대하여 초기 압력의 변화에 따른 평형 반 응 생성물, 연소온도, 생성물의 내부 압력 등을 자전연소 합성법의 열역학적 계산 프로그램인 'THERMO'를 이용 하여 계산한 결과이다. 이 그림에 의하면 반응기내 불활 성 가스압력이 증가함에 따라 연소온도와 실리콘 농도는 증가하여 가스압력이 2기압일 때 최고값에 달하고 있으 며, 미반응물인 $\mathrm{Mg}, \mathrm{SiO}, \mathrm{Mg}_{2} \mathrm{SiO}_{4}$ 는 점차 감소하여 그 농 도가 거의 Zero에 가까워짐을 알 수 있다.

Fig. 4는 반응식 1 에 의하여 $\mathrm{Mg}$ 입자크기를 20/60 mesh 를 사용하고, 성형압력을 $130 \mathrm{MPa}$ 로 고정하.ㄱ, $\mathrm{Mg}$ 몰비 를 변화시켰을 때 생성된 반응물의 침출전 X-ray 회절선 의 결과를 나타낸 것이다.

그림에서 알 수 있듯이 $\mathrm{Mg}$ 몰비가 증가할수록 미반응 된 $\mathrm{SiO}_{2}$ 상의 peak가 점차 감소되었고, $\mathrm{Mg}_{2} \mathrm{Si}$ 상이 증가됨 을 관찰할 수 있었으며, 2.6 몰에서 미반응된 $\mathrm{SiO}_{2}$ 상의 peak가 관찰되지 않음을 알 수 있었다. 이는 $\mathrm{Mg}$ 몰비가 증가함에 따라 $\mathrm{Mg}^{\circ}$ 이 $\mathrm{SiO}_{2}$ 의 $\mathrm{O}_{2}$ 와 반응하여 $\mathrm{MgO}$ 를 생 성하고, 그 반응열에 의해 남아있는 $\mathrm{Si}$ 와 $\mathrm{Mg}$ 의 반응으 로 $\mathrm{Mg}_{2} \mathrm{Si}$ 가 생성되었다고 추측된다. 이것은 $\mathrm{Mg}$ 의 몰비 가 증가할수록 반응 자체가 더욱 폭발적으로 일어나므로 $\mathrm{Mg}$ 의 기화가 촉진되고, 성형체의 부피가 팽창하여 $\mathrm{Mg}$ 과 $\mathrm{SiO}_{2}$ 의 접촉 상태가 불량하게 되어 반응이 완전히 이루 어지지 않고 미반응된 $\mathrm{SiO}_{2}$ 상이 존재하였다고 사료된다. 각각 몰비에 따른 반응 후 생성물의 형상을 보면 화학 양론적비 $(\mathrm{Mg} 2.0 \mathrm{~mol})$ 에서는 부피가 예비 성형체와 비슷 한 크기의 팽창을 보였지만, 화학론적양론비보다 많은 과 잉의 $\mathrm{Mg}$ 첨가에서는 예비성형체 보다 20 25\%의 부피팽 창을 보였다.

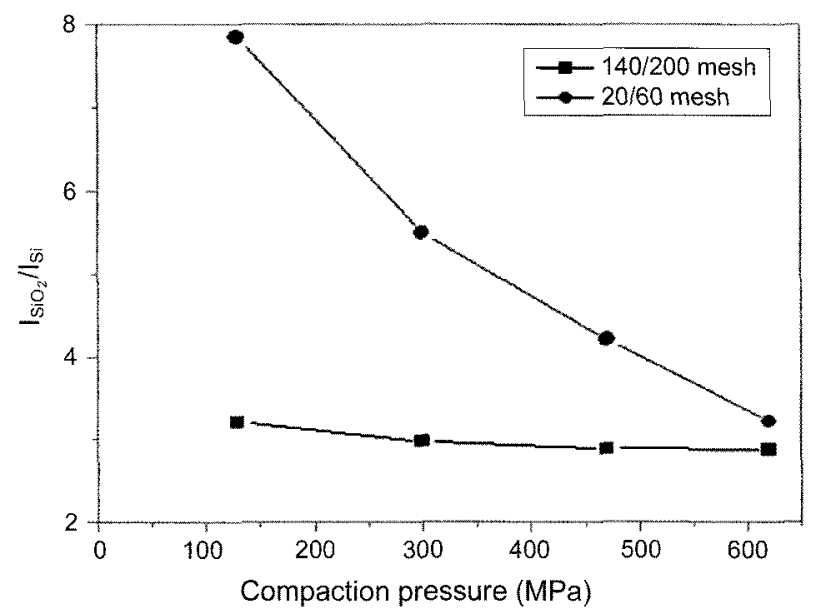

Fig. 5. Effects of the compaction pressure and $\mathrm{Mg}$ particle size on the relative intensity (Mg particle size 20/60 mesh, 140/200 mesh, Mg molar ratio $2.0 \mathrm{~mol})$.

\section{2. 생성물에 미치는 $\mathrm{Mg}$ 입자 크기의 영햠}

Fig. 5는 $\mathrm{Si}$ 과 $\mathrm{SiO}_{2}$ 의 $\mathrm{XRD}$ 상대강도에 미치는 $\mathrm{Mg}$ 입 자크기에 따른 성형압력의 영향을 나타낸 것이다. 본 연 구에 사용한 $\mathrm{Mg}$ 입자크기 20/60 mesh와 140/200 mesh를 사용하여 상대강도에 미치는 성형압력의 영향을 살펴보 았다. 일반적으로 성형압력을 증가시키면, 예비 성형체의 밀도가 증가함에 따라 치밀해지므로 접촉면적이 증가되 고, 따라서 완전한 반응이 일어난다고 사료된다. 따라서 본 연구에서는 $20 / 60 \mathrm{mesh}$ 를 사용했을 경우에는 $620 \mathrm{MPa}$ 에서 상대강도가 적어지는 최적의 성형압력 조건을 구하 였지만, $140 / 200 \mathrm{mesh}$ 를 사용했을 경우에는 성형압력을 증 가시켜도 거의 변함없는 일정한 결과를 얻었다. $\mathrm{Mg}$ 입자 가 클 경우에는 높은 성형압력을 주면 단위면적당 기공 의 감소를 유발시키기 때문에 접촉면적을 증가시키지만, 입자가 미세할 경우에는 낮은 성형압력에도 치밀화가 이 루어져 성형압력을 주었을 경우 별 영향을 얻지 못한 것 으로 사료된다.

Fig. 6은 입자크기에 따른 생성물의 X-ray 회절선을 나 타낸 것으로 입자크기가 클수록 미반응된 $\mathrm{SiO}_{2}$ 상 피크가 증가됨을 관찰할 수 있었다. 이는 분말의 입도가 커질수 록 반응물간의 접촉 면적이 감소하므로 반응물질들 간에 완전한 환원반응이 일어나지 않아서 미반응된 $\mathrm{SiO}_{2}$ 가 남 아 있다고 사료된다.

\section{3. 생성물에 미치는 산침출반응의 영향}

자전언소 고온반응기에서 반응 후 생성된 부산물인 $\mathrm{MgO}$ 등을 제거하기 위하여 산침출을 행하였다.

Fig. 7은 침출온도와 입자 크기에 따라 최종산물인 $\mathrm{Si}$ 의 회수율에 미치는 산침출의 영향을 나타낸 그림이다. 이때 침출온도의 영향을 알아보기 위해 염산의 농도(con., $18 \%$ ), 


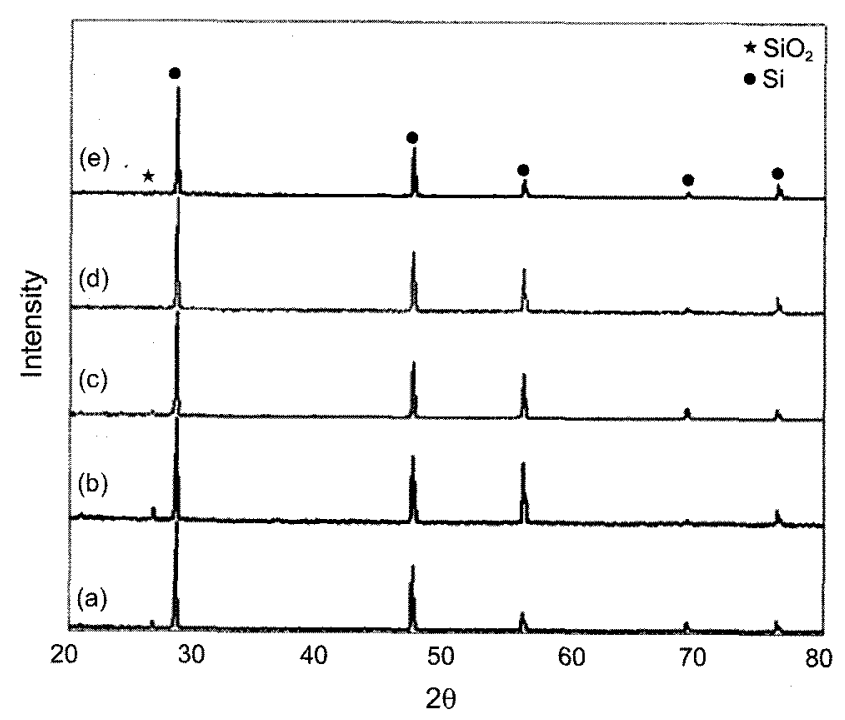

Fig. 6. X-ray diffraction of the product varying with $\mathrm{Mg}$ particle size after leaching $(\mathrm{Mg}$ molar ratio $2.0 \mathrm{~mol}$, compaction pressure $130 \mathrm{MPa}$ ); (a) 20/60 mesh, (b) 60/ 100 mesh, (c) 100/140 mesh, (d) 140/200 mesh, and (e) 200/325 mesh.

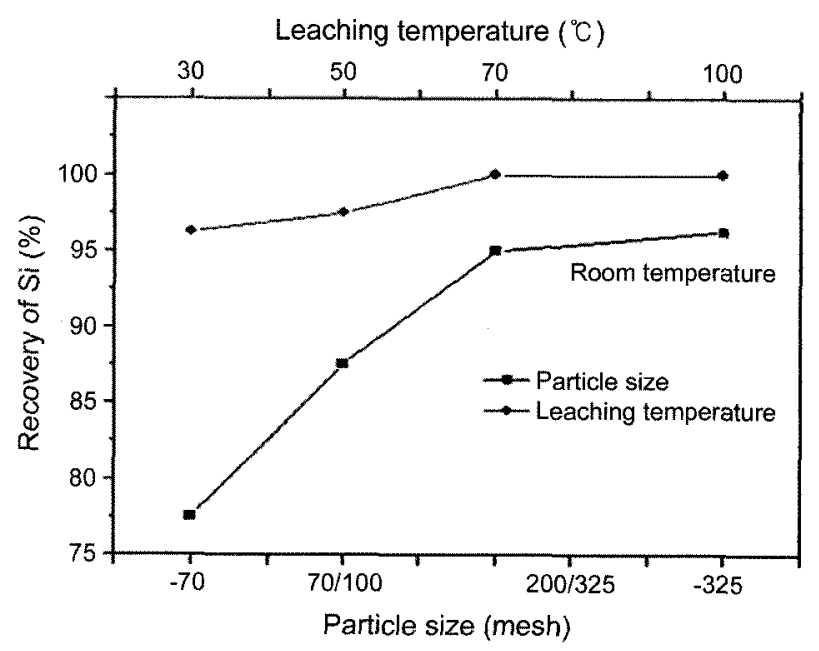

Fig. 7. Effects of the leaching temperature and Mg particle size on the recovery of the final product (Stirring speed $480 \mathrm{rpm}, \mathrm{HCl}$ conc. $18 \%$, time $3 \mathrm{~h}$, pulp density $3.2 \%$ ).

시료 $20 \mathrm{~g}$, 교반속도 $480 \mathrm{rpm}$, 침출시간 3시간으로 고정하 고 침출 전 연소반응물의 입자크기에 따라 실험을 행하 였으며, 이 결과에 의하면 침출온도가 증가함에 따라 $\mathrm{Si}$ 의 회수율은 증가하다가 $70^{\circ} \mathrm{C}$ 에서 약 $100 \%$ 를 보이므로 산침출이 거의 완료됨을 알 수 있고, 또한 $\mathrm{Mg}$ 입자크기 의 영향을 알아보기 위해 상온에서 위와 동일한 조건으 로 실험을 행하였을 때 역시 $\mathrm{Mg}$ 크기가 증가함에 따라 $\mathrm{Si}$ 의 회수율은 급격히 증가하다가 $200 / 325 \mathrm{mesh}$ 에서 $94 \%$ 로 최고치를 이루며 그 이상에서는 거의 일정하였다.

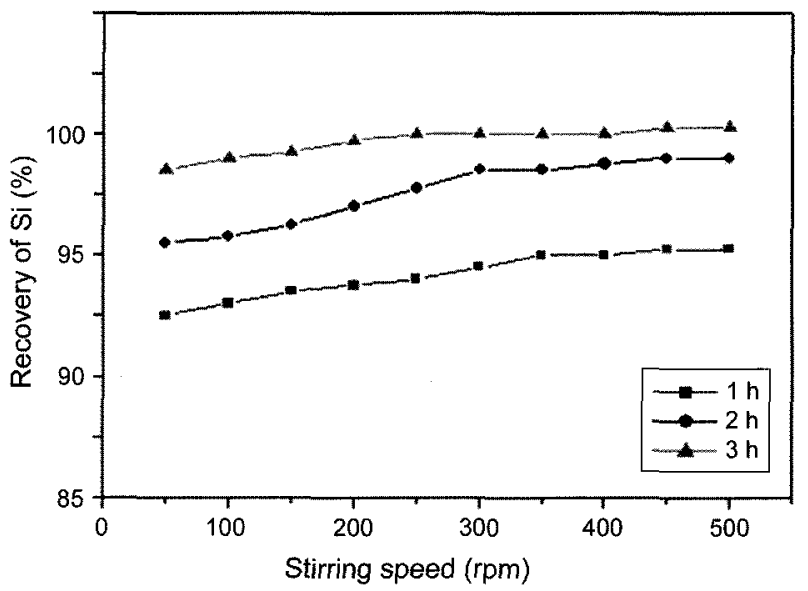

Fig. 8. Effects of the stirring speed and leaching time on the recovery of the final product (Particle size -325 mesh, temperature $70^{\circ} \mathrm{C}, \mathrm{HCl}$ conc. $18 \%$ ).

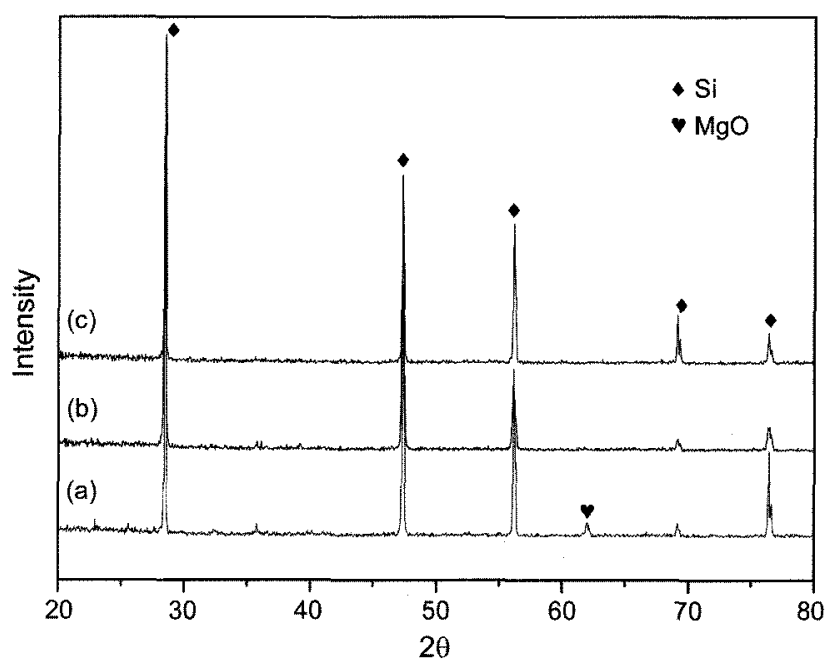

Fig. 9. X-ray diffraction patterns of the product varying with pulp density (Stirring speed $480 \mathrm{rpm}$, leaching time $3 \mathrm{~h}$, temperature $70^{\circ} \mathrm{C}$ ); (a) $3.8 \%$, (b) $3.2 \%$, and (c) $2.8 \%$.

Fig. 8은 위의 결과에 의한 최적조건으로부터 교반속도 와 침출시간의 영향을 나타낸 것이다. 그림에서 보는 바 와 같이 교반속도 및 침출시간이 증가할수록 $\mathrm{Si}$ 의 회수율 은 증가함을 알 수 있고, 적어도 3시간 이상 침출시간을 유지함으로 교반속도 $200 \mathrm{rpm}$ 에서 거의 $100 \%$ 의 침출율 을 얻을 수 있다. Fig. 9는 지금까지 얻은 최적 침출조건 에서 침출효과에 미치는 고-액의 용액농도영향을 나타낸 $\mathrm{X}-\mathrm{ray}$ 이다. 실험결과 최적의 용액농도는 $3.2 \%$ 이하인 것 으로 확인되었다. 즉 상대적으로 시료의 무게에 대한 침 출액의 부푀가 많을수록 용액상태에서 입자유동이 원활 하여 용질과 용매간의 접촉이 많아져 침출이 완전하게 진 행되었다고 생각된다.

Fig. 10 은 자전연소 고온반응에 의해 얻어진 생성물의 


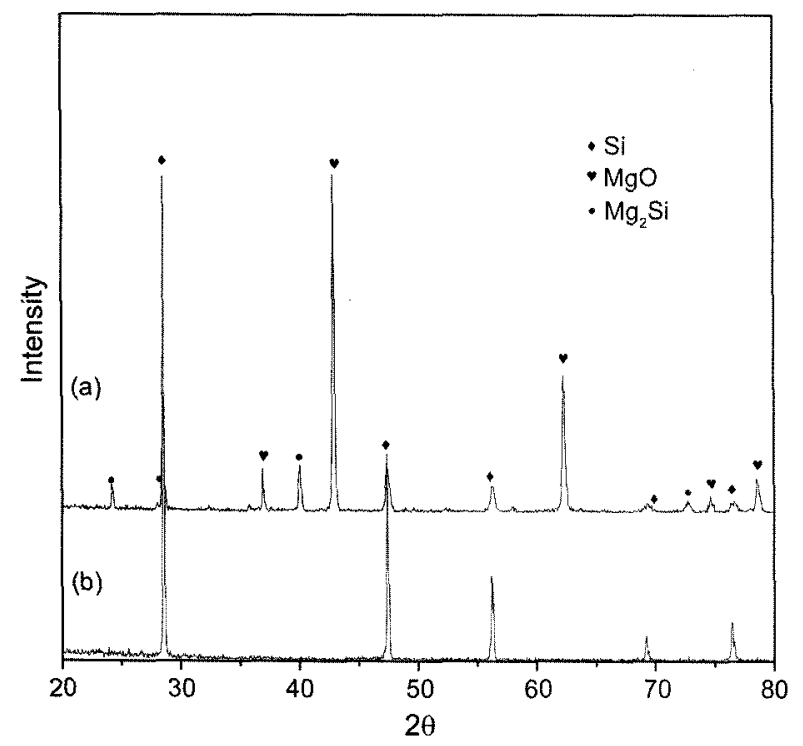

Fig. 10. X-ray patterns of the product before and after leaching (Stirring speed $480 \mathrm{rpm}$, particle size -325 mesh, temperature $70^{\circ} \mathrm{C}$, time $3 \mathrm{~h}, \mathrm{HCl}$ conc. $18 \%$, pulp density $3.2 \%$ ); (a) before leaching and (b) after leaching.

침출 전과 후를 비교한 것이다. 침출시험은 침출온도 $70^{\circ} \mathrm{C}$, 침출시간 3시간, 교반속도 $480 \mathrm{rpm}$, 입자크기 $325 \mathrm{mesh}$, 용액농도 $3.2 \%$ 의 최적 조건에서 행하였다. 또한 반응용 기에 존재하는 용존산소를 제거하기 위해서 고순도 질소 가스를 주입하면서 침출을 행하였다. 침출을 행한 후 증 류수로 수회 수세하였으며, 약 $100^{\circ} \mathrm{C}$ 이상의 건조기에서 충분히 건조하였다. 이 그림에 의하면 침출 후 $\mathrm{MgO}$ 등 불순물이 완전하 제거됨을 알 수 있었고, 이때 최종 생성 물의 불순물 함량을 ICP 분석한 결과 $99.9 \%$ 이상의 $\mathrm{Si}$ 순 도를 나타내었다. 또한 상기 최적조건으로 얻어진 최종 생성물의 SEM 사진을 Fig. 11에 나타내었으며, 사진에서 와 같이 약 $2 \sim 3 \mu \mathrm{m}$ 의 해면상구조의 구형분말을 언었다.

\section{4. 결 론}

자전연소 고온반응법을 이용하여 $\mathrm{SiO}_{2} / \mathrm{Mg}$ 계에서 $\mathrm{Mg}$ 몰 비, $\mathrm{Mg}$ 입자크기, 연소온도, 성형압력, 침출 등의 실험을 행한 후 다음과 같은 결론을 얻었다.

1. 자전연소 고온반응에서 $\mathrm{Mg}$ 입자크기가 작을수록, 성 형압력이 증가할수록 미반응물이 감소되었다. 이때 최적 조건은 $\mathrm{Mg}$ 입자크기가 $20 / 60$ mesh일 경우 $\mathrm{Mg}$ 몰비는 2.6

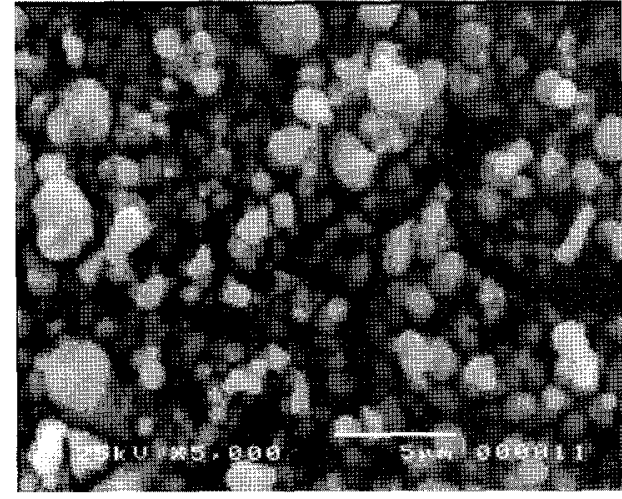

Fig. 11. SEM photographs of final product synthesized at optimum condition.

몰, 성형압력은 $620 \mathrm{MPa}$ 이었다. $140 / 200$ mesh일 경우에는 2.0 몰 이상이었다.

2. 침출 반응에서는 입자크기, 반웅온도, 교반속도, 반웅 시간이 증가할수록 침출효과는 증가하였으며, 이때 최적 조건은 침출온도 $70^{\circ} \mathrm{C}$, 입자크기 325 mesh 이하, 교반속 도 $480 \mathrm{rpm}$, 침출시간 3 시간, 용액농도 $3.2 \%$ 이었다.

3. 자전연소 고온반응법 및 침출 반응을 통한 최종 생 성물, 즉 실리콘 분말을 분석한 결과 순도 $99.9 \%$ 이상으 로 약 2 3 $\mu \mathrm{m}$ 의 해면상구조의 구형분말을 얻었다.

\section{REFERENCES}

1. J. H. Lee, W. K. Choo, and K. S. Go, "The Preparation of High-Purity Silicon by Hydrogen Reduction of Trichlorosilane," J. Kor. Inst. Met \& Mater., 14 [3] 288-95 (1976).

2. D. Kata, J. Lis, and R. Pampuch, "Combustion Synthesis of Multiphase Powders in the Si---C---N System," Solid State Ionics, 101-103 Part 1, November 65-70 (1997).

3. B. W. Jong, "Formation of Silicon Carbide from Silica Residues and Carbon," Bull. Am. Ceram. Soc., 58 [8] 788-89 (1979).

4. C. A. Slack, "Nonmetallic Crystal with High Thermal Conductivity," J. Phys. Chem. Solid, 34 321-35 (1973).

5. A. G. Merzhanov, "Combustion Processes That Synthesize Materials," J. Mater. Processing Tech., 56 [1-4] 222-41 (1996).

6. J. Kiser and R. M. Spriggs, "Soviet SHS Technology: A Potential U. S. Advantage in Ceramics," Ceram. Bull., 68 [6] 1165-67 (1989). 